\title{
Improving Secondary School Students' Translation Skills through Using Autonomous Learning Strategy
}

\author{
By \\ Prof /Ahmed Hasan Mohamed \\ Dr/ Esraa Ramadan El Sayed
}

Alhasan Mohamed Abdelwahid Ali 


\section{Abstract}

The present study aimed at investigating the effectiveness of using autonomous learning to improve secondary school students' translation skills. The participants of the study were (16) second year secondary school students who constituted an experimental group. It was a one group pre-post design. The instruments of the study was: a Translation Skills Test. A quasiexperimental design was used in the present study and $Z$ Value was applied. Results of the study showed that teaching the suggested program taught through the autonomous learning strategy significantly improved the post performance of the students' translation skills.

Keywords: Autonomous Learning, Translation Skills 
Improving Secondary School Students' Translation Skills through Using Autonomous Learning Strategy

استخدام التعلم الذاتي لتنمية مهارات الترجمة لاى طلاب المرحلة الثاتوية

أ.د/ أحمد حسن محمد د/ إسراء رمضان السيد أ/ الحسن محمد عبد الواحد علي

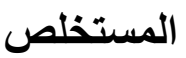

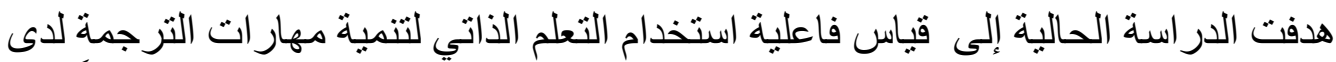

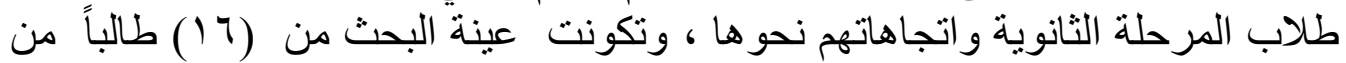

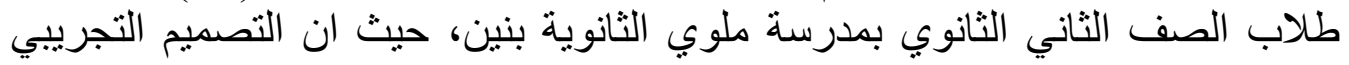

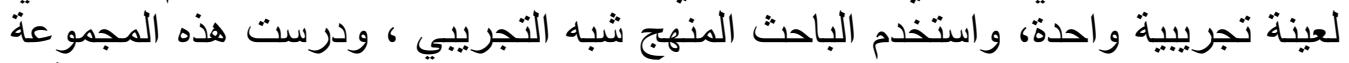

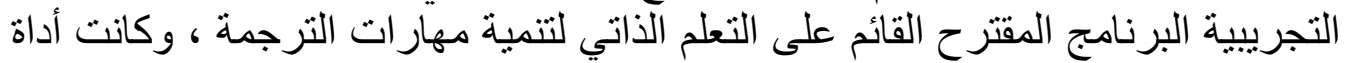

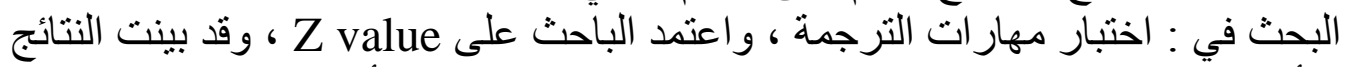

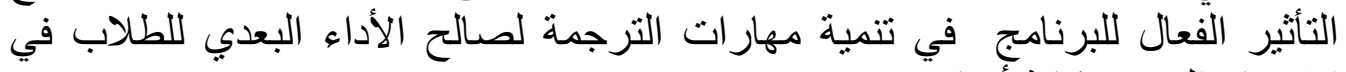
الاختبار البعدي بكافة أبعاده.

الكلمات المفتاحية : التعلم الذاتي ، مهارات الترجمة 


\section{Introduction}

People live in a world with international relations in several fields of life as in economics, science, and culture. Most international communications are performed in English. Demand in highly qualified translators has grown immensely for the last few decades. Translation is one of the oldest human practices both in its written and oral forms. Without doubt, translation is essential for making communication between people of different cultures possible. Yelena and Yuliya (2012) state that international communication is mainly performed in English. Knowledge of this language is a basic condition for getting access to the world scientific literature, doing business with foreign partners and integrating into foreign markets.

Translation is a means of reflecting the reality of life. Most people use two or more languages when travelling or when they resort to the internet. Translating from one language to another requires students to consider conveying the intended meaning accurately. Students need adequate mastery of vocabulary items, suitable language structures. When learners translate from Arabic into English or vice versa, they need to make proper use of grammatical rules in both languages. A good translation is one that carries all the ideas of the original as well as its structural and cultural features.

- There are several advantages of translation. Translation activities can improve the learners' verbal ability, expand their vocabulary and develop their style, grammar, and improve their awareness towards the culture of the target and source languages. A good translation is one that carries all the ideas of the original as well as its structural and cultural features.

Throughout history, translation has made inter-linguistic communication between peoples possible. The skill of translation gains increasing importance particularly these days. Several people 
in different parts of the world are interested in the translation process including scholars, men of letters and language learners.

\section{The importance of language translation}

Translation serves as a vehicle of communication among peoples. Gerding (2000:1) claims that "the main aim of translation is to serve as a cross-cultural bilingual communication vehicle among peoples." In the past few decades, this activity has developed because of rising international trade, increased migration, globalization, the recognition of linguistic minorities, and the expansion of the mass media and technology. For this reason, the translator plays an important role as a bilingual or multilingual cross-cultural transmitter of culture and truths by attempting to interpret concepts and speech in a variety of texts as faithfully and accurately as possible. What matters most in translation is the accurate and proper message delivery. Stephens (2016) mentions that if language is not correct, then what is said is not what is meant; if what is said is not what is meant, then what must be done remains undone; if this remains undone, morals and art will deteriorate. According to Yan (2016), translation is a necessity in foreign language classroom. When doing translation, students should be able to understand the materials well and be equipped with basic translation theories in order to promote their translation ability.

Translation has, no doubt, contributed a great deal to connect various cultures of the world, led to the enrichment of human knowledge, and led to the process of transferring messages across languages. By so doing, it makes it easy to develop cross-cultural interactions all over the world. About the importance of translation, Cook (2007), thinks that translation was an important part of English language teaching for a long time, but it has been abandoned since communicative methodologies became dominant. 
Interestingly, although translation was out of favour with English language practitioners, it has rather stubbornly refused to die in the teaching of languages other than English. On the same line, Ordudari (2008) mentions that human beings, throughout history, have made several efforts to take advantage of various methods of communication with the intention of utilizing the knowledge of other nations and endeavoring to preserve that knowledge for the coming generations. In today's world, communication between different nations with different languages is feasible through translation.

There are several perspectives with regard to translation. Bakir and Lazim (2010) mentioned several definitions of translation, though superficially different, seem to agree upon the point that this activity means conveyance of some sort of information from one language into another. This process that might appear simple is, in fact, painstaking if not arduous in some of its aspects, for it comprises transferring not only meanings of individual words or structures into the receptor language, but also stylistic features and implicational meanings. Translation, therefore, is a reproduction in the translated version of the thoughts and meanings implied in the original text where many structural and lexical adjustments can be used.

While Baker (1998) points out that translation is a separate academic discipline, Baker (1998:4) points out that translation is a separate academic discipline which, "like any young discipline, ... needs to draw on the findings and theories of the other related disciplines in order to develop and formulate its own methods." However, Gabr (2001:2) considers translation both a craft and a science, Gabr considers translation both a craft and a science when he writes that "translation being a craft on the one hand, requires training, i.e. practice under supervision, and being a science on the other hand, has to be based on language theories". However, claiming a literary translation to be a device of art, Herzfeld (2003:110) writes that literary translation used to release the text 
from its "dependence on prior cultural knowledge." Nonetheless Azizinezhad (2004:3) points out that translation has a lot in common with arts as well as sciences. It sometimes becomes highly dependent on the idiosyncrasies and intuition of the translator. Like composers and painters, translators often find their own moods and personalities reflected in their work. The major factor that prevents translation from being considered an art is that, unlike translators who have to solve a range of different problems, the defining factor of an artist's work is esthetics.

Gerding (2000) stated that consequences of wrong translation could be catastrophic. Mistakes made may be irreparable, like the translator in a hospital for a patient. Such mistakes could be a matter of life or death. Hence it is important to train translators in the acquisition and command of languages, translation strategies and procedures.

Al Shubaily (2008) investigated the effects of using the autonomous learning approach in teaching translation in developing translation skills and the attitudes towards the method of teaching. The sample of the students were two groups of the students in the commercial translation course at the College of Languages and Translation at King Saud University. The subjects of the study were sixty-seven female students at level eight attending the commercial translation course, and were divided into a control group (33 students) taught following the conventional method, and an experimental group (34 students) taught following the autonomous learning approach. The four main aspects tested in the study were; (1) lexical accuracy, (2) structural accuracy, (3) the overall accuracy of the students' translation, and (4) their attitude towards autonomous learning. The findings showed that there was no significant difference between the scores of the two groups in the lexical and structural accuracy, but the experimental group outperformed the control group in the overall accuracy. In addition, 
the study found that the subjects had a positive attitude towards autonomous learning. Bahameed (2008) also states that translators should be aware of and well acquainted with the cultural dimensions of the environment from which the SL text is taken.

\section{The difficulty of translation}

Generally, translating from one language into another is not an easy process. Bázlik (2009) remarks that "translation is not an easy task, especially when translating special pieces of text containing features not commonly found in English texts". Arabic and English exhibit different word orders. Hayeri (2014) states that when a text in a foreign language is translated into English, many of the features of the original language disappear. Arabic is, for the most part, a synthetic language. For instance, nouns are inflected for case and verbs are inflected for mood. Prosodically, each of the two languages has its own ways of versification and phonologically Arabic and English have different phonemic inventories. In addition, if one wants to assess the real hindrances of translation, one cannot ignore the geographical distance between Arabic and English settings, which resulted in a distance between Arabic culture and English culture. Therefore, one may classify the main hindrances of translation, which affect the quality of the translation outcome into: lexical hindrances, prosodic hindrances, structural hindrances, and cultural hindrances.

Boroditsky, Schmidt, and Phillips, (2003) mention that translations reveal several cultural differences in addition to intended and implied meanings. Certain specific expressions related to culture may cause another hindrance of sound translation as stated by Bakir and Lazim (2010). With regard to translating from Arabic into English, the translator must sometimes deal with texts containing proverbs, verses, historical incidents long forgotten, legendary personages, names of places, animals, plants, etc that are peculiar only to a specific culture. In addition, we must consider the normal difficulties in interpreting cultural contexts of 
worlds with completely different tastes and conventions such as the Arab world to the English-speaking world. When translating, a translator must bear in mind the fact that s/he should convey messages, not merely words. Taking this into consideration, the translator should be familiar with and sensitive to both cultures, the one which the text is translated from and the one the text is translated into.

\section{Context of the problem}

Although translation is considered a very important channel of intercultural dialogue, it has not been given due attention. Secondyear secondary school students are expected to get involved in translation tasks as part of their English lessons is mainly translation. The researcher observed that the pieces of translation are done in the classroom by the teachers of English. The teachers used to offer their students an English text and the students were invited to listen to their teacher and write the Arabic translation given in a traditional way. Instead of teaching them how to acquire translation skills, and how to decide on which lexical items and grammatical structures could be the best one to achieve the appropriate intended meaning, translation texts are given to them through dictating. In that way, teachers of English disregard the necessary skills required for their students after leaving school in the world of globalization. Our culture in Egypt and our educational system do not give enough space for learners of EFL in general and secondary school students in particular to acquire translation skills properly.

To clarify the translation problems that Mallawi second-year secondary school students encounter, the researcher conducted a pilot study on 20 students. The students were asked to translate tensentences: five from Arabic into English; and the other five sentences from English into Arabic. Based on their answers, it was 
found that the problems that the students encountered were mainly: difficulties in using appropriate lexical items, collocations, and grammatical structures, consequently, most of the students' translated texts were lacking the overall accuracy of the texts. So, the researcher thinks that the use of autonomous learning approach would hopefully improve the students' translation skills and provide them with many opportunities of discussion and decision making with regard to the use of accurate lexical items, collocations, and overall accuracy of the text.

Significance of the study

The present study is expected to be of benefit not only for students, but also for teachers and secondary school course designers.

1. Part of the significance of the present study is to shed light on the learner's over-reliance on the teacher which is regarded a serious problem in most teacher-centered classrooms.

2. The study offers the autonomous learning approach that can help learners change their behavior by encouraging them to take responsibility for their own language learning, to take part in the process of learning actively, decide on what and how to acquire the required skills.

3. The students will be able to use several resources to overcome and solve the problems they face in translating texts.

4. The study is significant to students through giving them responsibility for their learning in groups.

5. It is hoped that translation teachers would attempt to implement the suggested strategy in their classrooms. 
6. The present study also provides teachers with a practical example of classroom-based research in which the students become less dependent on their teachers.

7. Moreover, this study may serve as a common basis for further research attempting to investigate the effectiveness of using autonomous learning on the improvement of other language skills.

8. The present study sheds light to course designers to include autonomous learning-based translation activities in secondary school courses.

Aim of the study

There is one main aim for the present study; It is:

To investigate the effectiveness of using an autonomous learning strategy-based program on improving $2^{\text {nd }}$ year secondary school students' translation skills. That can be divided into :

a) To investigate the effectiveness of using an autonomous learning strategy-based program on improving $2^{\text {nd }}$ year secondary school students' use of lexical items.

b) To investigate the effectiveness of using an autonomous learning strategy-based program on improving $2^{\text {nd }}$ year secondary school students' use of collocations.

c) To investigate the effectiveness of using an autonomous learning strategy-based program on improving $2^{\text {nd }}$ year secondary school students' use of grammatical accuracy. 
مجلة العلوم التربوية ـ كلية التربية بالغردقة - جامعة جنوب الوادى

d) To investigate the effectiveness of using an autonomous learning strategy-based program on improving $2^{\text {nd }}$ year secondary school students' overall text accuracy.

Question(s) of the study

The present study attempted to answer the following questions:

What is the effectiveness of using an autonomous learning strategy-based program on improving second-year secondary school students' translation skill ? That can be divided into :

- What is the effectiveness of using an autonomous learning strategy-based program on improving $2^{\text {nd }}$ year secondary school students' lexical accuracy in translation?

- What is the effectiveness of using an autonomous learning strategy-based program on improving $2^{\text {nd }}$ year secondary school students' collocation accuracy in translation?

- What is the effectiveness of using an autonomous learning strategy-based program on improving $2^{\text {nd }}$ year secondary school students' grammatical accuracy in translation ?

- What is the effectiveness of using an autonomous learning strategy-based program on improving $2^{\text {nd }}$ year secondary school students' overall text accuracy in translation ?

Hypotheses of the study

The following hypotheses will be tested.

- There are statistically significant differences (favoring the post-experimental group) between the mean scores of the pre-experimental and the experimental groups on the post test of students' lexical, collocations, grammatical accuracy, and overall text meaning as measured by the post measurement of the students' Translation Test. 
- There are statistically significant differences (favoring the post performance) between the mean scores of the preexperimental and the post experimental performance on the post test of lexical items as measured by the post measurement of students' lexical items sub-test in translation.

- There are statistically significant differences (favoring the post performance) between the mean scores of the preexperimental and the post experimental performance on the post test of collocations as measured by the post measurement of students' collocations sub-test in translation.

- There are statistically significant differences (favoring the post performance) between the mean scores of the preexperimental and the experimental performance on the post test of students' structural accuracy as measured by the post measurement of students' grammatical accuracy sub-test in translation.

- There are statistically significant differences (favoring the post performance) between the mean scores of the preexperimental and the experimental performance on the post test of students' overall text accuracy as measured by the post measurement of students' overall text meaning sub-test in translation.

Delimitations of the study

- The participants were 16 male second year secondary school students from Mallawy public secondary school.

- The four main sub-skills to be included in the present study are; (1) The accuracy of lexical items, (2) The accuracy of collocations, (3) The accuracy of grammatical rules, and (4) overall text meaning. 
- The results of the study were delimited to the sample of the study during the second term of the school year 2016.

Definitions Of Terms

Autonomous learning: Dam (1995) defines autonomous learning as a matter of training learners to take charge of their own learning. The present study defines autonomous learning as an approach through which learners work in groups and each individual is supposed to be responsible for playing a specific role in a classroom learning activity while the teacher is a helper and a guide.

Translation: Translation is a broad term which can be understood in many different ways. Newmark (1991:27) defines the act of translating as: "transferring the meaning of a stretch or a unit of language, the whole or a part of a text, from one language to another". Based on Oxford Advanced Learner's Dictionary (2003), translation is simply defined as the process of changing something that is written or spoken into another language. According to Hatim and Munday (2004:3-4), translation is a process or a product, and can be classified into sub-types as literary translation, technical translation, subtitling and machine translation. To the present study, translation is the transfer of meaning of a text from one language to another.

Accurate translation: According to Gambier (2014) a successful translation is one which conveys the explicit and implicit meaning of the source language into the target language as fully and accurately as possible. However, in the present study, the accuracy of a translated text is determined in the light of the accurate representation of the message in both languages.

Collocations : The researcher defines a collocation as mainly two words that accompany each other and have a certain meaning. 
Translation and relevant arguments

The main arguments and assumptions that have been provided against the use of translation as a language teaching tool could be summarized, as follows:

Many authors such as Duff (1989); Zabalbeascoa (1990); Sankey (1991); Carreres (2006); Malmkjaer (2010); Vermes (2010); Mogahed (2011); and Pan and Pan (2012) claim that translation has nothing to do in the communicative approach to language teaching.

1) Duff (1989) claims that "translation is a boring and nonstimulating task."

2) Zabalbeascoa (1990:76) thinks that "translation is an artificial exercise in which the main emphasis is on reading and writing and students do not practice oral skills".

3) Sankey (1991:418) states that "translation tasks have nothing to do with the way in which a mother language is learnt, so they do not promote natural FL learning."

4) Marley (1994) thinks that translation is considered something 'boring', 'pointless', 'difficult', 'irrelevant' and at last, 'uncommunicative' because traditionally, many English teachers associate translation activities with grammar translation as a method.

5) Carreres (2006) claims that "translation can be particularly frustrating and de-motivating for students."

6) Carreres (2006) claims that "translation tasks are useless and do not resemble real world practice, since translators normally operate into and not out of their mother tongue. 
7) Malmkjaer (2010:186) claims that "translation provides a simplistic and false belief that there is a perfect one-toone relationship between the native language and the foreign language.

8) Vermes (2010:84) argues that "translating is not the aim of language learning, it is the aim of translator training and both are independent fields of study."

9) Mogahed (2011) mentions that 'translation is not suitable for all learners, since it can only work well with those interested in literature or with those which have already acquired a significant level of proficiency in the FL.

10) Pan and Pan (2012:4) think that "translation involves the use of two languages and, thus, deprives students of opportunities to receive sufficient FL input."

Despite these claims which are against the use of translation in the language classroom, recent studies show that translation can be a great aid to foreign language learning. Counterarguments for all of the assumptions above mentioned have also been put forward:

Karimian (2013). defends his idea of using translation to promote learners of English as a foreign language, "with the growing importance of learner-centered language teaching, researchers have attempted to lighten the load of language learning, and have investigated what is helpful for learners to arrive at their objective in the most economical way. Among them, the use of translation." Karimian (2013) states that translation is a supporting factor in language pedagogy in order to learn and improve learners " Ttranslation assist the students to improve their knowledge of English regarding different skills and solve language problems. Simões et al. (2013) think that the act of translation from one language to another is very much a natural and spontaneous mental 
action of many individuals who are in contact with more than one language.

Bataineh (2002) investigated the problems that face EFL students in translating idioms into Arabic. The participants of the study were 45 students from both Yarmouk University and the University of Jordan. The researcher designed a test consisting of 45 items varied in their difficulty. The study revealed the problems arising from the students' translation of idioms into Arabic are: "The loss of some shade of meaning", misunderstanding the meaning of the sentence, disrupting the coherence of the text, and "unintelligibility through the use of literal translation". Also, the study revealed that the most problematic idioms for students were phrasal verbs, idioms with verbs, idioms with verb to be, idiomatic words, adjective and nouns in combination, and idioms with adverbs respectively.

Jarvella, et al. (2002), state that good translation requires knowledge and competences to be brought together. These include knowledge in specific subject domain, theoretical and functional knowledge about human language and its use, knowledge of the source and target languages, and understanding the linguistic genre being used. Moreover, the researcher thinks that competence in translation includes the ability to understand and produce texts adequately in relation to the purpose of a communication.

Mahmoud (2005) investigated EFL learners' lexical errors and collocation errors. An essay-writing test was used as the tool of the study. A total of 420 collocations were found in 42 essays written by Arabic-speaking university students majoring in English. About two thirds of these collocations (64\%) were incorrect and $80 \%$ of these were lexical collocations as opposed to grammatical ones. Sixty one percent of the incorrect combinations could be due to 
negative transfer from Arabic. He called them "unnatural" word combinations.

Al-Hassan (2007) investigated the ability of EFL learners in Bahrain to comprehend unfamiliar multiword units to assess the ability of Arab EFL majoring students in guessing the meanings of those lexical collocations through translation. A sample of students was chosen. An inference task was designed to collect the data. The results revealed that the students were unable to come up with the correct translation in nearly half the number of items that contained unfamiliar lexical collocations. On the other hand, the participants provided correct or partially correct translation in the rest of items.

Badawi (2008) investigated EFL Saudi prospective teachers' ability to translate culture-bound expressions and their awareness of their translation strategies. A sample of 43 fourth-year university students was chosen in Tabuk. A translation test and a translation questionnaire were used to collect data. The participants were asked to translate 20 items and to respond to the translation awareness questionnaire by ticking the strategies they used for translating the test items. Results revealed that $86.05 \%$ of EFL Saudi students were unable to translate the test items. Also, he discovered that students' translation strategy awareness was poor as they got $40.24 \%$ and that cut-off level was $50 \%$.

Kohil (2009) investigated the difficulties of finding an equivalent in translating English idiomatic phrasal verbs into Arabic. She aimed to explore how student's linguistic competence influenced their translation process. Twenty five third year students were selected randomly to answer a written translation test. The results showed that the errors made by students were more than their correct answers. They also showed that students confronted problems when translating idiomatic phrasal verbs from English into Arabic. The main causes of the students' difficulties were related to their restricted linguistic competence, the literal meaning and their background knowledge. 
Dweik and Abu Shakra (2010) investigated the difficulties encountered by EF learners, From the English translations produced by the sample of 50 Saudi students majoring in English, it was found that the translation of Arabic collocations into English was extremely difficult and the overwhelming majority followed literal translation after relying mainly on bilingual dictionaries.

Boussalia (2010) studied the difficulty which some Algerian EF students faced when they translated English texts into Arabic. She found out that such a difficulty was because of the linguistic and cultural differences between English and Arabic. Literal translation was one of the reasons why Arab students could not translate into English correctly. Translating Arabic collocations into English was the most difficult areas for them.

Alrishan and Smadi (2015) investigated the difficulties that Jordanian EFL University students encounter in translating English idioms into Arabic. The participants of the study were all students at Yarmouk University and the University of Jordan who were selected purposefully. The total number of the students who participated in the translation test which contains 16 idioms of different categories was 90. The quantitative findings of the study revealed that EFL Jordanian university students encountered difficulties in translating English idioms into Arabic.

Husni \& Newman (2015) mentioned three difficulties that students used to face when translating or interpreting a collocation. They were: recognizing a collocation in a text, comprehending it, and reproducing that collocation in the target language

Alqaed (2017) mentioned several translation problems encountered by Arab learners of EFL. Students' errors included errors in their use of lexical items, errors related to semantic and syntactic differences between both the source and the target 
languages. It was found that most learners' errors when translating English lexical collocations was due to inaccessible collocation dictionaries, semantic, syntactic differences between the two languages. Affording bilingual dictionaries was recommended.

Because it is not possible to match vocabulary items and grammatical rules on a one-to-one item basis between the source language and the target language texts, possible artificial sentences could be found.

Approaches to the teaching of translation

Teaching translation in a foreign language classroom differs from that for professional purposes. The Grammar Translation Method was used when the main emphasis was on the use of word lists, bilingual glossaries, detailed grammar discussing and bilingual dictionaries. The teacher used to use his her mother tongue for translating at the expense of the target language. Accordingly, translation into the foreign language was the major means to apply, consolidate and test the lexis and grammar of the foreign language

Although the Grammar Translation Method is now almost universally rejected in foreign-language teaching, still it has a remarked influence on many teachers and on translation activities.

Many studies have dealt with approaches of the teaching and learning of translation such as: Dias (2000), Kiraly (2000), Newmark (2001), Snel-Trampus (2002), Vickers and Ene (2006), Nord (2009), Gile (2009), Darwish (2011), Clavijo and Marín (2013), Yan

(2016)

Dias (2000) tested the effects of introducing information and communication technology into selected oral English classes in Japan. The students were attending a Japanese university specializing in health and animal sciences, and were required to enroll in a course that had speaking and listening skills as primary focus. The study aimed at freeing the learners from dependence 
on teachers. The results showed that the participants in the information and communication technology classes made greater efforts to speak English with their classmates and teachers. They were also more likely to anticipate a need for English in their future lives.

Kiraly (2000) proposed his own approach based on: "collaborative learning, social constructivism, empowerment and reflexive practice to teach translation". Kiraly(2003) referred to the collaborative learning environment as the place where students learn, guided by their professors. They facilitate the individual construction of knowledge to solve complex and real problems, which develop cognitive flexibility and self-concept to solve translation problems.

Authors like Newmark (2001) represent the traditional approach, which bases its methods on translation manuals, traditional language teaching and the translation practice. He describes translation methods depending on how close they are to the source or to the target language.

Snel-Trampus (2002) describes two approaches that are usually followed in translation classrooms. Norm-based and target audience-centred approaches. In the former, students are usually more sensitive to the linguistic aspects. They deal with the microlevel of the text, and only in an advanced phase they become able to grasp the text as an organic whole. For a translation problem they give a tentative solution as a first hypothesis and then they ask their colleagues or teachers for error elimination. On the other hand, the target audience-centred approach requires the translator's awareness of the social and psychological contexts of both the target and source languages. Snel-Trampus proposes that translation trainees should refer to peers or teachers only for error elimination. 
All the above presented approaches can be complemented with the principles mentioned by Hurtado (2005:130), who states that there are three basic elements in any translation teaching process, that are: "translation as what is going to be taught, translator's competence as knowledge and abilities required to translate, and the acquisition of the translator's competence as the mean to develop this competence

Nord (2009) emphasizes that translation teaching should be similar to the real practice of translation. She proposes the "functionalist didactics" that includes criteria to select texts to be translated in class, how to classify translation problems and procedures, how to monitor students' progress, and how to evaluate translations.

Darwish (2011) investigated the effectiveness of using autonomous learning to improve ESP college students' translation skills. A translation Test and an attitude scale towards learning English were used. Forty eight male and female students were randomly assigned to either a pre-experimental or an experimental group. The students of the experimental group were instructed using autonomous learning, whereas, the pre-experimental group received traditional treatment. Compared to the students of the preexperimental group, the students of the experimental group showed significant differences in their total translation skills. There was evidence of a significant improvement of the experimental group students' attitudes towards translation.

Karimian (2013) investigated Iranian English learners' use of translation as a learning strategy to learn English. The study employed quantitative and supplemental qualitative methods. Iranian EFL learners (170) were asked to answer the Inventory for Translation as a learning strategy. For the qualitative survey, 120 students were selected to respond the learners' interview guide. Results revealed that language learners used a wide variety of learning strategies concerning translation to comprehend and remember as well as produce English. 
Translation as a Professional Approach

Professional translation is a specialized skill that requires specialized training. This approach aims at providing students with as much "real-world" practice as possible so they can become competent professionals. Learners are expected to learn more about professional techniques and to translate more 'realworld' texts. They study translation as an end in itself, and not only as a means to learn. Students are expected to be prepared for the market, and translation activities in class should help them build skills for their future careers.

Here, translation is an end in itself and it is a skill acquired on the basis of language proficiency. In translator training, the objective of translation is to acquire translation skills. Colina (2003:6) states that even though current trends both in language and translator training favour a communicative approach by concentrating on language in communication rather than language as a formal construct, there is a marked difference between the two. In language training, the language is the object of study and learners try to get as close as possible to native competence, a competence which is then accessed for production. In the case of translation, language is used as a tool and the emphasis is no longer on competence but performance since the translator has to focus on "particular instantiations of language use, in specific texts and contexts.

Clavijo and Marín (2013) state that professional translation teaching strategies aim at identifying the best way to develop translators' competencies in Modern Language students, who were supposed to work for companies as language experts, including translation as one of their tasks. Tools of the study included theoretical research compared to a survey applied to students of financial and economic translation and showed how their professors 
used to apply different teaching strategies, resources, activities and assigned roles. It also included how students interacted in classroom compared to the real translation practice, the languages they combined in their translations and the textual genres used. Finally, the study recommended the use of current teaching strategies. Therefore, professional translators should undergo permanent training and their productive capacity should not be measured in terms of pages, words or hours done, but rather taking into account the quality of the output or finished work.

Translation as a product approach

According to the product approach to the teaching of translation, in the beginning, the students are given a text in the source language and are asked to read the whole text in a short time and start translating. Translation is often done by the teacher who used to dictate the translated text in the target language. The same exercise is repeated with the texts written in the other language. The students are often passive learners as they used to receive the translated text without spending any recognized effort to acquire the translation skills. It is essential to care for students' needs and their varied expectations of acquiring translation skills. With the traditional product approach it is difficult to keep students' motivation levels up because learner's needs are not always met.

Translator's interviews and diaries based approach

It is an approach towards teaching of translation. It depends on the use of translator interviews and diaries. With diaries, students get a chance to write down thoughts either during a translation or after it. This individualistic approach gives them the chance to reflect on the process. There is a risk that some students may feel self-conscious, as they know the diaries will be read by the teacher, but they also often like the idea of their being read, and therefore listened to, and that their experience and feelings are taken into account by their trainer. If used regularly, 
encourage students to reflect on their work, thereby giving the trainer an idea of the progress made and eliciting introspective information. Fox (2000: 127) thinks that personal and individual aspects of the student's experience would surely be reflected in a diary and recommends using that method more widely in class.

Fox (2000) recommends splitting students into small groups and asking them to translate something together. Fox (2000: 129) also states that "studies have shown that working in groups during a translation class is perceived as beneficial to students' learning experience in terms of reader expectations and development of responsibilities as a translator." During group work, students are encouraged to discuss and defend their translations, think about decisions, and serve as guides and critics to each other. Zeng and Lu-Chen (2002: 59) claim that students learn best through social interactions which allow them to work toward a common goal, by sharing information and solving the same problems.

However, Gile (2005) advocates the use of evaluation exercises which incorporate the process-orientated approach and the product-orientated one. He thinks that that mixture gives the students time to reflect on different aspects of their performance and progress.

\section{linguistic-oriented translation approach}

The linguistic-oriented translation theorists often used the linguistic trends of the time for their approach towards translation. Nida and Taber (1982), for example, relied heavily on Chomsky's transformational grammar, while House (1977) drew on text linguistics. Central to most of their efforts was the desire to establish criteria for the production and evaluation of translations as well as lay down guidelines for the training of prospective translators. This linguistic approach to translation is therefore also 
known as the normative or prescriptive approach.

Translation as a functional approach

The functional approach is mainly seen in contrast to the linguistic/equivalence-based approach to translation. Ersozlu (2016) Recent developments in many fields such as international relations, business, trade, social sciences, and technology and the need for accessing information in the shortest possible time necessitate an active and effective communication medium. Translation, notably interpretation, is one of those communication media.

According to schäffner (2004) the functional approach allows a challenge for universities is thus to design programs which give their students good job opportunities, and then constantly ensure that the programs are in line with the needs of the diverse and rapidly changing industry. Teachers need to bear in mind that they are dealing with a rapidly changing market, which means that the training translation programmes need to be flexible and adaptable to keep pace with industry needs.

Nord (1997: 117) mentions why the functional approach is useful in translation teaching, stating that it encourages translation teachers to move away from equivalence-based principles and take a wider view of what translation entails. Accordingly, that has facilitated a more profession- and practice-oriented translator training and permitted the inclusion of a wide variety of activities professional translators are asked to perform.

Communicative approach

Marley (1994) states that language competence is a two-way system. Learners need to be able to communicate both ways: It is necessary to translate into and from the foreign language. Translation is a perfect means for practicing this vital skill. Stressing the communicative aspect of language training, means 
that authentic texts must be chosen and the communicative situation taken into consideration by giving clear translation briefs Translation should become an objective in foreign-language training. Skopos (1998) sees translation as a type of communicative action. The translated text is judged as well-done if it is meaningful to the target-culture receiver. Nord (1997: 32) clarifies that idea mentioning that the translated text "should make sense in the communicative situation and culture in which it is received."

Clavijo and Marín (2013) attempted to identify the best way to develop translators' competencies. The sample of the study were the students were supposed to work for companies as language experts, including translation as one of their tasks. The study was based on theoretical research compared to a survey applied to students of financial and economic translation and showed how their professors applied different teaching strategies, resources, activities and assigned roles. It also included how students interacted in classroom compared to the real translation practice, the languages they combined in their translations and the textual genres used. The students were assessed. The socioconstructivist approach was recommended as a teaching approach.

\section{Autonomy and language learning}

Learner training and learner autonomy are two concepts that bear the same meaning. Recently, there has been considerable interest in these concepts as a necessary condition of effective learning. Chan (2001) mentions that it is seen as an issue principally of students taking greater control over the content and methods of learning. It grows out of the individual's acceptance of his or her own responsibility for learning. The learner is perceived as a decisionmaker who has, or will develop, the capacity for choosing among 
available tools and resources to create what is needed for the task at hand.

In the autonomous learning approach, as stated by both Little (1996) and Chan (2003), the roles of both learners and teachers are different from their roles in the conventional or teacher-centred approaches. While in the latter teachers control all aspects of teaching and learning, the former emphasizes that learners take control of the learning process by having choices over what and how to learn, and teachers are portrayed as helpers, facilitators, resources, consultants, counsellors, coordinators, and advisors.

Sharp (2002) conducted a study to assess the benefits of using some learning activities taking place outside school hours on developing self-regulated learning skills and learners' sense of autonomy. It was found that the learners became more motivated. External factors such as rewards or threats were found to have less impact on learners' motivation towards learning. She adds that such study support programs assist learners to commit their free time to outside the class activities and also to the improvement of their metacognitive skills. In their study Spratt et al (2002) tried to assess students' readiness for learner autonomy, and the results revealed that motivation had a strong impact in this readiness.

Thus, autonomous learning is an approach, which views students to have more active and participatory roles in the learning and teaching process than in traditional approaches. Additionally, this approach requires different classroom activities, the structures of which are decided by students themselves resulting in more and more students' involvements in classroom activities. The teacher is less likely to dominate classroom events. Consequently, teachers and learners will work collaboratively for the curriculum development and learners will be allowed to make decisions on content selection, methodology and evaluation

The above presented approaches mentioned three basic elements in any translation teaching process: what is going to be 
taught, translator's competence or skills required to translate. It should be mentioned that the translator should be aware of the Arabic vocabulary items, pronunciation differences and even grammatical features that are not the same of the English language. The researcher thinks that when learners are in a new situation they are expected to explore that situation and to discover and master the environment. This applies to translation training. With using autonomous learning, the students are expected to be more likely to enjoy translation training activities.

\section{Commentary}

Based on the literature survey of the present study, it seems that the debate with regard to approaches to the teaching of translation, translators' skills and competencies will continue. There are common criteria for translation. Every translation should sound as if it never existed in a foreign language. That means when someone translates from English into Arabic, for instance, the reader of the Arabic text should not notice that it is a translated text. Therefore, a good translation is easily understood, and should be fluent and smooth, idiomatic, convey, to some extent, the literary subtleties of the original, and convey, as much as possible, the meaning of the original text. The researcher thinks that still there is a need to try new approaches and strategies to the teaching of translation.

From the previous presentation and discussion of studies on translation problems and autonomous learning, it is evident that most of them dealt with the application of autonomous learning approach in second or foreign language settings. Rare studies investigated the effects of using the autonomous learning approach in Arab settings. Moreover, to the knowledge of the researcher, there has not been an attempt to tackle this issue especially in translation training of Egyptian secondary school students. 
Study Design

It is a quasi-experimental study, where both quantitative and qualitative data are obtained and analyzed to find answers for the questions of the present study.

\section{Participants}

The participants of the study consisted of a sample of sixteen male second year secondary school students. They were all from Mallawy secondary school for males. Their ages ranged between 16 and 17 years old. The students were assigned as an experimental group. The participants have been studying English as a foreign language. They had almost similar social background and of the same public school.

Variables of the Study

\section{The independent variable is:}

Using a suggested autonomous learning strategy-based program to improve second-year secondary school male students' translation skills

\section{The dependent variable was:}

Students' translation skills (the accuracy of using lexical items, collocations, proper grammatical rules, and the overall text meaning).

Instruments of the study

A pre-post Translation Skills Test was prepared and used by the researcher in conducting the present study.

Pre-Post Translation Skills Test

The pre-post translation test was given to measure the students' ability to translate using accurate lexical items, collocations, and 
appropriate structures. The test was submitted to a group of jury members who were specialists in the field of TEFL to check the familiarity and suitability of the test contents for the subjects of the study.

\section{Construction of Pre-Post Translation Skills Test}

The Translation Skills Test consists of two main parts. In Part One, the students are invited to translate from English into Arabic. In Part Two, the students are invited to translate from Arabic into English.

\section{Scoring of the Translation Skills Test}

Four marks are given for each well translated sentence The maximum score for the Translation Skills Test is [100 marks]. See Appendix " $\mathrm{B}$ " The test was submitted to a group of jury members who judged the practicality and suitability of the test to the sample of the present study. The instructions of the test are brief, easy to understand and free from any possible ambiguities.

Validity of the Translation Skills Test

To ensure validity of the test, the researcher submitted it, in its initial form, to a number of specialized jury members. The jury members were invited to comment on:

- Clarity of the questions.

- Clarity of the test instructions.

- Suitability of the translation units to the level of the target sample.

The test items were modified according to the Jury members' comments and suggestions. See Appendix (B) for the final form of the test. 
Reliability of the Translation Skills Test

To establish the reliability of the test, it was administered to a sample of 30 second year secondary school students other than the sample of the study. Then, after two weeks, the same test was administered to the same group under nearly similar conditions. The reliability coefficient of the test was estimated by using Cronbach Alpha Formula. The estimated value was (0.76), which is considered reliable for the purpose of the current study.

The program

General aim of the program

The general aim measuring the effectiveness of using a suggested autonomous learning-based program to improve 2 nd year secondary school students' translation skills.

\section{Learning Objectives}

By the end of each lesson, the students are expected to be able to:

1. identify the proper meaning of lexical items included in each translation unit;

2. identify the sentence structure of the source translation unit ;

3. analyze the sentence structure to re-formulate it in the target language.

4. work out to what grammatical rule is most suitable for the target translation unit,

5. use the same grammatical structure but to give the same message in the target language.

6. use their own words to give the same message in the target language 
Contents of the Program

The program consists of two units based on the following:

Unit One: includes English translation units.

Unit Two: includes Arabic translation units.

\section{Material and Method of Teaching}

English and Arabic translation units have been chosen according to the results of an informal discussion with several secondary school teachers of English, a sample of 30 second year secondary school students and after the advice of a group of jury members, as those texts were suitable for target students and for the study. The Program includes two units. The total number of the lessons are sixteen. Each lesson lasts for 45 minutes. Students should be given opportunities to consult dictionaries, grammar books, look for a required information form the internet, etc. while they are doing their translation tasks.

The program lasted eight weeks and was taught through the autonomous learning strategy as it helps acquiring and applying translation skills in real life situations and calls for real discussions inside classroom.

The procedure of teaching

1) Before administering the program, the researcher explained the purpose of the study and the students agreed to participate.

2) The students are divided into groups of fours. Every one of in the group is expected to share in the translation process. 
3) Student (A), Student (B), Student (C), and Student (D), are responsible for lexical items, collocations, structural accuracy, and overall text accuracy respectively.

4) Every time, the students change roles with the change of the translation unit. Thus, every student is expected to share in every part of the translation process. They may discuss ideas related to translation under the supervision of the teacher.

5) Appropriate feedback from the teacher should be given to the students to let them know whether the translated text is well-done or not.

Duration of the Study

This program was taught during the second term in 2016 and lasted eight weeks

Z-Value was used here because the number of the students of the experimental group was 16 (less than 20).

\section{Pre-post testing}

The hypothesis predicted that there would be statistically significant differences between the mean scores of the preexperimental and the post-experimental groups on the overall post testing of students' translation skills in favor of the postexperimental group.

The post testing sum of ranks of the students' performance on Translation Skills Test (TST) for the pre-experimental and the postexperimental groups were (136.00) and (392.00) respectively. So, based on a $\mathrm{z}$-value of $(-4.84)$, it is possible to state that there was generally statistically significant difference in the total effectiveness of the program. See the following Table:

\section{Table}


Improving Secondary School Students' Translation Skills through Using Autonomous Learning Strategy

Ranks on the Translation Test (Pre-Post-Testing)

\begin{tabular}{|c|c|c|c|c|c|}
\hline & group & $\mathbf{N}$ & $\begin{array}{l}\text { Mean } \\
\text { Rank }\end{array}$ & $\begin{array}{l}\text { Sum of } \\
\text { Ranks }\end{array}$ & $\mathrm{Z}$ \\
\hline \multirow{3}{*}{ Lexical post } & $\begin{array}{l}\text { Pre- } \\
\text { Experimental }\end{array}$ & 16 & 8.69 & 139.00 & \multirow{3}{*}{-4.76} \\
\hline & $\begin{array}{l}\text { Post- } \\
\text { Experimental }\end{array}$ & 16 & 24.31 & 389.00 & \\
\hline & Total & 32 & & & \\
\hline \multirow{3}{*}{$\begin{array}{l}\text { Collocations } \\
\text { post }\end{array}$} & $\begin{array}{l}\text { Pre- } \\
\text { Experimental }\end{array}$ & 16 & 9.81 & 157.00 & \multirow{3}{*}{-4.16} \\
\hline & $\begin{array}{l}\text { Post- } \\
\text { Experimental }\end{array}$ & 16 & 23.19 & 371.00 & \\
\hline & Total & 32 & & & \\
\hline \multirow{3}{*}{ Grammar post } & $\begin{array}{l}\text { Pre- } \\
\text { Experimental }\end{array}$ & 16 & 9.25 & 148.00 & \multirow{3}{*}{-4.49} \\
\hline & $\begin{array}{l}\text { Post- } \\
\text { Experimental }\end{array}$ & 16 & 23.75 & 380.00 & \\
\hline & Total & 32 & & & \\
\hline \multirow{2}{*}{ Overall } & $\begin{array}{l}\text { Pre- } \\
\text { Experimental }\end{array}$ & 16 & 9.47 & 151.50 & \multirow{2}{*}{-4.31} \\
\hline & $\begin{array}{l}\text { Post- } \\
\text { Experimental }\end{array}$ & 16 & 23.53 & 376.50 & \\
\hline
\end{tabular}

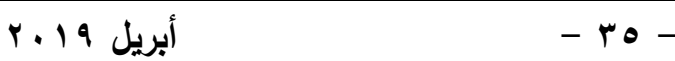




\begin{tabular}{ll|l|l|l|l}
\hline & Total & 32 & & \\
& Pre- & 16 & 8.50 & 136.00 & \\
& Experimental & & & & \\
Total post & $\begin{array}{l}\text { Post- } \\
\text { Experimental }\end{array}$ & 16 & 24.50 & 392.00 & -4.84 \\
& Total & 32 & & & \\
\hline
\end{tabular}

It was evident that the students of the post-experimental group performed much better on the post-translation skills test (TST) than on pre-testing. Thus, the suggested program and the autonomous learning strategy were significantly effective in improving secondyear secondary school students' translation skills. The use of the autonomous learning strategy was found highly effective in enabling the students use lexical items, lexical and grammatical collocations properly. In addition, as observed, using the autonomous learning strategy encouraged the students to get involved in the translation process. Compared to the performance off pre-testing, the post performance of the the students was much better during the translation process. There were statistical significant differences between the ranks of performance of the pre and post testing on the translation sub-skills test, (favoring the postperformance).Analysis of the data using z-ranks shows that $\mathrm{z}$-value of the post comparison of the pre-experimental and postexperimental groups in the four sub skills: lexical accuracy, collocation accuracy, grammatical accuracy and overall text accuracy (-4.76), (-4.16), (-4.49) and (-4.31) successively are significant. Generally, the results of the present study supported the hypothesis that the suggested program was effective in improving the students' translation skills. Thus, the hypothesis was confirmed.

\section{Discussion}

Initially, many students were uncomfortable with process of translation, as it was the first time for them to be trained to translate 
depending on the autonomous learning strategy. After providing them with an introductory lesson showing them the procedure they were supposed to follow, they became more cooperative and less resistant to the process of translation.

It was found that some students produced inappropriate translations as they did not have sufficient knowledge of the collocations of both languages, grammatical rules, and the lexical items.

One of the problems that perplexed the students was the presence of unknown words. That problem slowed down the translation speed of students and disabled them to deal with other problems. When a student encountered an unknown word, he used either to ask the help of the group members, consult the available manual or electronic dictionary, or resort to the teacher's help. However, in several times, many students were able to guess the meaning of the unknown words by using contextual clues. Many students used to re-express each translation unit in two or even three different ways without changing the original meaning of the source text. Most students experienced loss of meanings due to a number of reasons such as those cultural lexical, and grammatical differences between Arabic and English languages.

a) The major area of translation difficulty was related to differences between the source and target cultures. Examples were found in the students' translated tests of "أخي الاكبر" , " "توصل الي قرار" ,"تقوم بأعمال المنزل " , " دليل ساطع " ,"احترام كبير" , "العا" into "big brother", "big respect"; " make the wok of the house"; "arrived to a decision" whereas the proper accepted translation should be "elder brother"; "great respect"; "strong evidence"; "do the house work"; "come to a decision". 
b) Several linguistic and stylistic difficulties in translation were often due to the differences between the source and target linguistic systems. Many students made errors in the translation of tenses, passive, complex sentences, word order, adjectives, adverbs, and punctuation. See Appendix (H).

c) Other students made errors in translation by the addition or the omission of the definite article "the".

d) Several students found considerable difficulties in guessing the appropriate meanings of the lexical collocations because they were unfamiliar with such collocations or because they had not enough practice in using such collocations in meaningful sentences. That led the students to translate poorly. Because adjectives follow nouns in Arabic whereas precede them in English, many students made errors in that respect during the process of translation. During each lesson evaluation, the researcher used to discuss such problematic areas with the students with an aim of raising the students' linguistic awareness.

Although many students could not avoid the trap of word-forword translation. It was observed that many students acquired the skill of looking for the suitable required lexical items, proper grammatical structures, suitable word order, and the overall intended text meaning. According to everyone's role, they worked together in fours in order to achieve proper translation. The researcher was available for offering help whenever needed. It was necessary for the researcher to clarify uncommon grammar structures and word order to the students. It was evident that the students who were exposed to the suggested training autonomous learning-based program exhibited more active and more democratic, stress-free participations. There was an increased activity accompanied by noise. Although the researcher used to encourage the students to engage in the translation process, noise was there as a healthy evidence of discussion. When it comes to translating collocations, most students used to face a problem 
finding suitable equivalents of collocations in the target language (TL). Those problems could be syntactical, cultural, and semantic. The students tended to translate them literally without their connotative meaning. Sometimes they had to resort to literally translate those items. Problems in translation made by the students could be classified into two main types: Errors that hindered communication and others that did not. Mistakes can be ignored if they do not impair the comprehension of the text and do not mislead the addressee. Thus a wrong preposition may be tolerable if it appears in the context that clearly shows which meaning has been intended. If, however, the wrong preposition changes the meaning completely, the translation, good as it may be from other points of view, is unacceptable.

Several students made errors when they had to use linking words such as "although", "but", "and", "yet" and "then". Such linking words are important in English, as they are used to show the relationships between the words in sentences. Most students did not find any reason to use any other linking word rather than "and" thinking that there was nothing wrong done in doing so.

It was also observed that when the students resorted to dictionaries, they tried to get the meaning of the difficult lexical items without taking their context in consideration. Those who chose to translate on a dictionary-free basis found the process of translation more time-consuming. The students had the chance to share ideas of translation with each other, debate meanings of lexical items and collocations, as they were working in groups. The students could learn from working together as a team. The researcher had to move quietly from group to group encouraging, making notes, offering help when needed.

Actually, based on field observation and the statistical results of the present study, the students could: 
1. learn in a real-world classroom setting where they worked together and had opportunities for discussion as they worked cooperatively to properly translate the intended "translation unit".

2. employ autonomous learning because it allowed them to cooperate in choosing from among several options in order to translate properly.

3. produce translated units that are directed toward real audiences.

4. develop their knowledge through student- student interactions and student-teacher interactions.

5. listen attentively to and respect others' opinions.

6. ask for teachers help when needed.

7. choose a "spokesman" to show their final work. That, in turn, created a democratic atmosphere inside the classroom.

8. concentrate upon the overall text meaning of the translation units.

9. recognize that sound translation requires exercising effort and concentration.

10. gain confidence and feel a real sense of pride in work that they personally plan for.

Among the difficulties encountered by the students, their poor ability in using both manual and electronic dictionaries.

Apart from spelling and punctuation issues, translation problems regarding collocations and lexical items were found the most frequent problems. Mother tongue was found a serous reason for committing such errors in translation. 
The researcher thinks that the poor performance of the students' translated units could be attributed to one or more of the following reasons:
a) Students' mother tongue interference
b) Students' lack of culture knowledge let them commit errors of idioms which are culture-bound expressions.
c) Students' lack of grammatical competence.
d) Students' clinging to bilingual dictionaries

\section{Challenges}

It goes without saying that there is no perfect theory or approach to the teaching of translation. Despite the remarkable effectiveness of the autonomous learning strategy, the researcher still thinks that much more research should be completed in order to offer learners better learning. Better results could have been obtained were the students involved in using specialized dictionaries as:
a) Bilingual English-Arabic dictionaries
b) Collocational dictionaries

However, the researcher encountered many problems throughout the study; dividing the students into groups of fours was not easy as that was a totally new strategy for the subjects of the study and it took much effort from the researcher to convince the learners of its benefits. Another problem was in trying to convince the students of the benefits of group work during the process of translation

Conclusion

العدد الرابع


The improvements that have occurred in the students' translation skills were due to the effectiveness of using the suggested autonomous learning strategy-based program. It can be concluded that the results of the present study agree with the results of many authors such as those of Posen (2006) who stresses that translation can be a very successful tool for a comparative study of both languages

The results of the present study also coincide with those of Jarvella, et al. (2002) who stressed that state that good translation requires knowledge and competences to be brought together The results of the present study also coincide with those of Vickers and Ene (2006), Al-Hassan (2007), Badawi (2008), Bázlik (2009), Darwish (2011), Alrishan and Smadi (2015), and Husni \& Newman (2015) who stressed that most of the difficulties encountered by learners of English as a foreign language arise from translating word for word regardless of the cultural and linguistic differences between the source language and the target language ( Arabic and English).

There is also an agreement with other authors: Altan and Trombly (2001), Sharp (2002), and Hobrom (2004) who assured the benefits of using some learning activities such as learnercentered activities including autonomous learning.

Recommendations

Based on the results of the present study, the researcher would like to make the following recommendations to $2^{\text {nd }}$ year secondary school students, teachers and course designers:

1. Second year secondary school students should be trained on two types of translation activities: from Arabic into English and from English into Arabic.

2. Second year secondary school students should study the differences and similarities between Arabic culture and English culture in order to be able to translate appropriately. 
3. The students should consult their classmates, teachers, and dictionaries whenever needed.

4. The students should avoid literal translation as much as possible because Arabic and English belong to two different families with different linguistic systems.

5. Teachers should avoid using traditional methods of teaching translation.

6. Teachers should train the students to translate starting from easy to difficult units of translation.

7. Teachers should introduce translation difficulties and problems in details. To raise the students' awareness of word order and grammatical differences between both the target and the source languages, the teacher should illustrate through giving examples of word order, in both languages (Arabic and English).

8. Teachers should help students pay attention for cultural, conceptual and grammatical difficulties in both languages.

9. Teachers should comment on the committed errors in the translated texts with students to let them be acquainted with their errors.

10.Teachers should help the students decide to use an appropriate translation equivalent (lexical items or collocations) when they are not able to translate using the original forms which are culture-bound.

11.Teachers should provide the students with several examples of collocations to become more familiar with them and do better on translation activities.

12.Teachers should encourage students to use both

العدد الرابع




$$
\text { مجلة العلوم التربوية ـ كلية التربية بالغردقة - جامعة جنوب الوادى }
$$

monolingual and bilingual dictionaries.

13.Teachers should help the students identify their areas of weakness and give them correct and valid translation against which they can measure their own translation.

14.Teachers should make use of recent teaching techniques in an attempt to remedy the problems theirs students usually face during translation.

15.Course designers should afford general-purpose dictionaries as well as:

c) Bilingual English translation dictionaries;

d) Collocational dictionaries

16.Course designers should leave a room, in the students' English course, to train them on manual/electronic dictionary use.

Recommendations for Future studies

Future research is needed to identify the most problematic cultural areas encountered by second year secondary school students when they translate from Arabic into English or vice versa.

1. Future research is needed to investigate the effectiveness of using autonomous learning on improving secondary school female students' translation skills.

2. Further research is needed to examine the effectiveness of using autonomous learning on the performance of second year secondary school students in translation for a longer period.

3. Further research is needed to examine the effectiveness of using autonomous learning on second year secondary school students' performance of oral translation.

4. Further research is needed to investigate the effectiveness of 
Improving Secondary School Students' Translation Skills through Using Autonomous Learning Strategy

using autonomous learning on solving some problems of translation where the students do their translation activities with or without dictionaries.

5. Future research is needed to design an autonomous learningbased program as a remedy of second year secondary school students' translation difficulties and problems

6. Future research is needed to identify the interference of Arabic language in translating from Arabic to English. 
References:

Abdel-Hafiz, Ahmad-Sokarno (2000). Problems in translating English journalistic national universities. Translation Journal, Vol. 6, No. 1.

Ahmed, Shameem (2015). Attitudes towards English Language Learning among EFL Learners at UMSKAL, Journal of Education and Practice, Vol.6, No.18

Al Ghussain, Reem Abed Al Latif (2003). Areas of cultural and linguistic difficulty in English-Arabic translation. Doctoral thesis, Durham University. Available at Durham E-Theses Online: http://etheses.dur.ac.uk/1416/

Al Ghussain, Reem Abed Al Latif (2003). Areas of cultural and linguistic difficulty in English-Arabic translation. Doctoral thesis, Durham University. Available at Durham E-Theses Online: http://etheses.dur.ac.uk/1416/

Al Shubaily, Sarah Ahmad (2008). Autonomous Learning in Teaching Translation: A Comparative Study between Conventional Teaching and Autonomous Learning, An M.A. Thesis The Department of English at the College of Arts, King Saud University.

Al-Hassan, H. (2007). In guessing the meaning of idioms: Efficiency and techniques. Unpublished M.A Thesis, University of Bahrain. Retrieved on $15^{\text {th }}$ Oct, 2012 from http://search.proquest.com. ezlibrary.ju.edu.jo/docview /304773490?accountid=27719

Alhumaidi, Majd et al. (2015). Contrastive analysis : Differences between Arabic and English in the basic sentence structure.

$22 r \cdot 10 / 11 \%$ https://www.slideshare.net/rsminiramiin/difference- 
between-english-and-arabic-basic-sentence-structure

Ali, Shamim (2012). Integrating Translation into Task-Based Activities -A New Direction for ESL Teachers. Language in India 12: 429-438

Alqaed, Mai Abdullah (2017). Perceptions on L2 Lexical Collocation Translation with a Focus on EnglishArabic, Journal of Education and Practice,8(6),pp128133.

Alrishan, A.., Smadi,O.(2015). Strategies Used by Jordanian EFL University Graduate Students in Translating Idioms into Arabic. Journal of Education and Practice. 6,(6),4555.

Alsop, D. T. (2006). The impact of increased student choice on learner autonomy in a second-year Spanish course. Dissertation Abstracts International, Vol.67, No.9. (UMI No. 3232145)

Altan, M.Z. and Trombly, C. (2001). Creating a learnercentered teacher education program. ELT Forum, Vol.39, No. 3, 28-3

Ashouri, Amir F. and Zahra Fotovatnia (2010). The Effect of Individual Differences on Learners' Translation Belief in EFL Learning. English Language Teaching 3(4): 228-236.

Azizinezhad, M. (2004). Is translation teachable? Retrieved $17 / 04 / 2007$

from http://accurapid.com/journal/36edu.htm

Badawi, M. (2008). Investigating EFL prospective teachers' 
مجلة العلوم التربوية ـ كلية التربية بالغردقة - جامعة جنوب الوادى

ability to translate culture-bound expressions. University of Tabuk. Retrieved on $11^{\text {th }}$ Nov, 2012 from http://www.eric.ed.gov

Bahameed, Adel Salem (2008). Hindrances in Arabic-English intercultural translation, Translation Journal and the Author URL. Retrieved 01/03/2008 from http://translationjournal.net/journal/43culture.htm

Bahumaid, S.A. (1995). On the teaching of translation at the university level, Turjuman, Vol.4 No.2, 95-104.

Baker, M. (1992). In other words: A course book on translation. London: Routledge.

Baker, M. (Ed.). (1998). Encyclopedia of translation studies. London: Routledge.

Bakir, Kadhim H. and Lazim, Hashim G. (2010). Stylistic problems confronting Arab students in Arabic-English translation, URL. $\quad$ Retrieved $01 / 03 / 2010$ from http://translationjournal.net/journal/43culture.htm

Bataineh, R; Bataineh, R (2002). The Difficulties Jordanian Graduate Learners of English as a Second Language Face When Translating English Idioms into Arabic. RASK: internationalt tidsskrift for sprog og kommunikation 16: 33-83.

Bázlik, Miroslav (2009). Common errors committed in translating (not only) legal documents. Brno Studies in English,Volume 35, No. 1, ISSN 0524-6881

Brockbank, Eileen. (2001). The translator is a writer. Translation Journal 5(2). Available at: http://accurapid.com/journal/16prof.htm

Boroditsky, L., Schmidt, L. A., \& Phillips, W. (2003). Sex, syntax, 
and semantics. In D.

Boussalia , Selma. 2010. Students' Difficulties in English-Arabic Translation of Collocations Case Study: Third Year Students of English, Unpublished MA dissertation, Mentouri University- Constantine, Algeria.

Butzkamm, Wolfgang and John Caldwell (2009). The bilingual reform: A paradigm shift in foreign language teaching. Tubingen: Narr Studienbücher.

Carreres, Ángeles (2006). Strange Bedfellows: Translation and Language Teaching.

Chan, V. (2001). Readiness for learner autonomy: what do our learners tell us? Teaching in Higher Education, Vol.6, No.4, 505-518.

Chan, V. (2003). Autonomous learning: the teachers' perspectives. Teaching in higher education, Vol.8, No.1, 33-55.

Chiu, C. (2005). Teacher roles and autonomous language learners: a case study of a cyber English writing course. Dissertation Abstracts International, Vol.66 No.12. (UMI No. 3202483)

Clavijo, Bibiana and Marín, Patricia (2013). Identifying Translation Teaching Strategies: An Exploratory Study, International Journal of Humanities and Social Science, Vol. 3 No. 21 [Special Issue-December.,

Clavijo, Bibiana and Marín, Patricia (2013). Identifying Translation Teaching Strategies: An Exploratory Study, International Journal of Humanities and Social Science, Vol. 3 No. 21 [Special Issue - December 
Clavijo, Bibiana and Marín, Patricia (2013). Identifying translation teaching strategies: An exploratory etudy, International Journal of Humanities and Social Science Vol. 3 No. 21 [Special Issue - December].

Clavijo, Bibiana and Marín, Patricia (2013). Identifying Translation Teaching Strategies: An Exploratory Study, International Journal of Humanities and Social Science, Vol. 3 No. 21 [Special Issue - December.,

Colina, Sonia. (2003). Translation Teaching From Research to the Classroom a Handbook for Teachers. Boston: McGraw-Hill Companies.

Colina, Sonia. 2009. Further Evidence for a Functionalist Approach to Translation Quality Evaluation. Target 21 (2), pp. 235-64.

Cook, G. (2007). Viewpoint. A thing of the future: translation in Language learning. International Journal of Applied Linguistics. Vol.17, No.3, Pp.396-401.

Cook, Guy (2010). Translation in Language Teaching: an Argument for Reassessment. Oxford: Oxford University Press.

Cresswell, A. (2000). Self-monitoring in student writing: developing learner responsibility. ELT Journal,Vol.54, No.3, Pp. 235-244.

Darwish, Mohamed Abdelwahid Ali (2011). The effects of using autonomous learning on improving second-year Faculty of Law students' translation skills and attitudes towards translation,

Dam, L. (1995). Learner autonomy: from theory to classroom practice. Dublin: Authentik Ltd. Research in Education and Psychology. Faculty of Education, 
Menia University, October, 24(2),

Defeng, L. (1999). The teaching of commercial translation in Hong Kong: problems and perspectives. Babel, Vol.45,No.3, Pp.193-204.

Deolinda Simões, Helga Guincho and Isabel Magalhães, "Teaching Languages to European Computer Science Students in an Engineering Institute in Portugal: Translation Approaches in the English, German and French Classroom." e-TEALS: An e-journal of Teacher Education and Applied Language Studies4 (2013): 46-70. ISSN 1647-712X

Dias, J. (2000). Learner autonomy in Japan: transforming 'help yourself' from threat to invitation. Computer Assisted Language Learning, Vol. 13, No.1, Pp.49-64.

Duff, Alan (1989). Translation. Oxford: Oxford University Press.

Dweik and Abu Shakra (2010). Strategies in Translating Collocations in Religious Texts from Arabic into English, Atlas Global Journal for Studies and Research. July 19, 2010.

Ellili, M. \& Chaffin, E. (2007). Emirate students' readiness for autonomous language learning. In Jendli, A., Troudi, S. \& Coombe, C. (Eds.) The power of language: perspectives from Arabia. Dubai: TESOL Arabia. Retrieved 11/05/2009 from http://repository.ksu.edu.sa

Ersozlu, Elif (2016).Training of Interpreters: Some Suggestions on Sight Translation Teaching. Retrieved on 25th September 2016, available at 
مجلة العلوم التربوية ـ كلية التربية بالغردقة - جامعة جنوب الوادى

http://www.translationdirectory.com/article755.htm

Fernández-Guerra, Ana. (2014). The Usefulness of Translation in Foreign Language Learning: Students' Attitudes. International Journal of English Language \& Translation Studies Vol-2, Issue-1, 153-170. Retrived from http://www.eltsjournal.org

Fox, O. In Schäffner, C., Adab, B. (eds.) (2000) Developing Translation Competence, Amsterdam: John Benjamins Publishing Company

Gabr, Moustafa. (2000). Reassessing Translation Programs in Egyptian National Universities: Towards a Model Translation Program. Master's thesis, Washington International University, Pennsylvania, USA.

Gabr, Moustafa. (2001). Program evaluation: a missing critical link in translator training. Retrieved 03/04/2007 from http://accurapid.com/journal/15training.

Gentner and S. Goldin-Meadow (Eds.), Language in Mind: Advances in the Study of Language and Thought, pp. 61-79. Cambridge, MA, US: MIT Press.

Gerding, Salas. (2000). Teaching translation: problems and solutions. Translation Journal, Vol.4, No.3.

Gile, D. (2009). Basic Concepts and Models for Interpreter and Translator Training. Amsterdam: John Benjamins

Gile, D. (2005) 'Training students for quality : ideas and methods', Paper given at the IV Conference on Training and Career Development in Translation and Interpreting. Universidad Europa de Madrid

González Davies, M. (2004) Multiple Voices in the Translation 
Classroom, Amsterdam: John Benjamins Publishing Company.

Guerra, Ana B. F. (2014). The Usefulness of Translation in Foreign Language Learning: Students' Attitudes, IJ-ELTS, Vol. 2, issue 1, Pp. 153-170.

Hatim, B. \& Munday, J. (2004). Translation: An advanced resource book. New York: Routledge.

Hayeri, Navid (2014). Does gender affect translation? Analysis of English talks translated to Arabic M.A. Thesis, Austin : The University of Texas.

Herzfeld, M. (2003). The unspeakable in pursuit of the ineffable: representations of untranslatability in ethnographic discourse. In P. G. Rubel \& A. Rosman (Eds.), Translating culture: perspectives on translation and anthropology. Oxford: Oxford University Press.

Hobrom, A. I. (2004). Online resources and learner autonomy: a study of college level students of Arabic. Dissertation Abstracts International. (UMI No. 3150595)

Husni, R. \& Newman, D. (2015). Arabic-English-Arabic Translation: Issues and strategies. London: Routledge.

Hurtado, A. (2005). La adquisición de la competencia traductora aspectos teóricos y didácticos en Didáctica de la traducción y la terminología. Colección estudios de traducción y terminología volume 2. p. 17 - 50. Universidad del Valle.

Hussein,R., Khanji,R., \& Makhzoumi, K. (2000). Idioms: Transfer or what?.Language and Translation 
مجلة العلوم التربوية ـ كلية التربية بالغردقة - جامعة جنوب الوادى

Journal,12,23-34, King Saud University.

Jabak, Abdullah and Mustapha (2016). The difficulty of translating collocations from Arabic into English encountered by a sample of Arab students, e-ISSN : 2289 8042, VOL 3 BIL 1 (JUN 2016)

Jarvella, R. J., Jensen, A., Jensen, E. H., \& Andersen, M.S. (2002). Towards Characterizing Translator Expertise: some findings using TAPs and experimental methods. Cambridge: Cambridge University Press.

Karimian, Zeinab (2013). Students' use of translation as a learning strategy in EFL classroom, Journal of Language Teaching and Research, Vol. 4, No. 3, pp. 605-610.

Kavaliauskienè , G. (2010). Skills of reading, writing and translating in English for specific purposes. Buckingham Journal of Language and Linguistics, Vol. 3.

Kavaliauskienë, Galina and Ligija Kaminskienë (2007). Translation as a learning tool in English for specific purposes. Kalbotyra 57(3): 132-139.

Kiraly, D. (1995). Pathways to Translation.Pedagogy and Process. Kent (O), Londres: The Kent State University Press.

Kiraly, D. (2000). A Social Constructivist Approach to Translator Education : Empowerment from Theory to Practice. Manchester. St. Jerome Publishing.

Kiraly, D. (2003). From Instruction to Collaborative Construction: A passing fad or the promise of a paradigm shift in translator education? en Baer B. y Koby G. (eds.) Beyond the Ivory Tower. Rethinking translation pedagogy. American Translators Association Scholarly Monograph Series, Vol. XII. Amsterdam, Filadelfia: 
John Benjamins. 3-27.

Kiraly, D. (2003). From Instruction to Collaborative Construction: A passing fad or the promise of a paradigm shift in translator education? en Baer B. y Koby G. (eds.) Beyond the Ivory Tower. Rethinking translation pedagogy. American Translators Association Scholarly Monograph Series, Vol. XII. Amsterdam, Filadelfia: John Benjamins. 3-27.

Kiraly, D. (2003). From Instruction to Collaborative Construction: A passing fad or the promise of a paradigm shift in translator education? en Baer B. y Koby G. (eds.) Beyond the Ivory Tower. Rethinking translation pedagogy. American Translators Association Scholarly Monograph Series, Vol. XII. Amsterdam, Filadelfia: John Benjamins. 3-27.

Kohil, H.(2009) .Investigating Problems in Translating English Idiomatic Phrasal Verbs into Arabic. M.A Thesis. Mentouri University of Costantine, Algeria.

Kussmaul, Paul. 1995. Training the Translator. John Benjamins Publishing Co.

Leonardi, Vanessa (2010). The Role of Pedagogical Translation in Second Language Acquisition: From theory to practice. Bern: Peter Lang.

Liao, Posen (2006). EFL Learners' Beliefs about and Strategy Use of Translation in English Learning. Regional Language Centre Journal 37 191-215.

Little, D. (1996). Learner autonomy: some steps in the evolution of theory and practice. The Irish Yearbook of Applied 
مجلة العلوم التربوية ـ كلية التربية بالغردقة - جامعة جنوب الوادى

Linguistics, 16, 1-13.

Littlewood, W. (1999). Defining and developing autonomy in east Asian contexts. Applied Linguistics, Vol.20, No.1, Pp.71-94.

Long, L., (1996). Discarding illusions for practical work. Linguistic journal, 22 (2), 38-44.

López, J. y Minett J. (2001). Manual de traducción Inglés Castellano. Gedisa, Barcelona.

López, J. y Minett J. (2001). Manual de traducción Inglés Castellano. Gedisa, Barcelona. Newmark, P. (2001). A Textbook of Translation. Edinburgh. Pearson Education Limited.

López, J. y Minett J. (2001). Manual de traducción Inglés Castellano. Gedisa, Barcelona.

Mahmoud, Abdulmoneim (2005). Collocation errors made by Arab learners of English, Asian EFL Journal, Vol.5 July.

Malmkjaer, Kristen (2010). Language learning and translation, in Yves Gambie rand Luc Van

Mezmaz, M. ( 2009). Problems of Idioms in Translation. Unpublished M.A Thesis. Mentouri University of Costantine, Algeria.

Mogahed M. Mogahed (2011). To Use or not to Use Translation in Language Teaching. Translation Journal 15(4).

Mok, O. (1995). Accessibility of specialized lexicon as criterion for quality assessment of legal translation. Babel, Vol. 41, No.4, Pp.193-208.

Newmark, P. (1988). A textbook of translation. London: Prentice 
Hall International.

Newmark, P. (1988). A textbook of Translation. New York: Prentice Hall.

Newmark, P. (2001). A Textbook of Translation. Edinburgh. Pearson Education Limited.

Newmark, P. (2001). A Textbook of Translation. Edinburgh. Pearson Education Limited.

Newmark, Peter. (1991). Approaches to Translation. GB: Multilingual Press.

Nord, Christiane (2009). El funcionalismo en la enseñanza de traducción at Revista latinoamericana de traducción Mutatis Mutandis Vol. 2 No. 2, p. 209-243 taken from:

Nord, Christiane (2009). El funcionalismo en la enseñanza de traducción at Revista latinoamericana de traducción Mutatis Mutandis Vol. 2 No. 2, p. 209-243 taken from:http://aprendeenlinea.udea.edu.co/revistas/index.p hp/mutatismutandis/article/view/2397/2080

Nord, Christiane. (2009). El funcionalismo en la enseñanza de traducción at Revista latinoamericana de traducción Mutatis Mutandis Vol. 2 No. 2, p. 209-243 taken from: http://aprendeenlinea.udea.edu.co/revistas/index.php/mu tatismutandis/article/view/2397/2080

Ordudari, Mahmoud (2008). Good translation: art, craft, or science?

Translation Journal, Vol. 12, No.1, January.

Orellana, Marina. 1994. La Traducción del Inglés al Castellano.

Guía para el Traductor. Editorial Universitaria. 
Oxford Advanced Learner's Dictionary (2003). Oxford: Oxford University Press. Retrieved 15/10/2010 from http://www.thefreedictionary.com/movie

Pan, Yi-chun and Yi-ching Pan (2012). The Use of Translation in the EFL Classroom, The Philippine ESL Journal 9: 423.

Ross Nigel J. (2000). Interference and Intervention: Using Translation in the EFL Classroom. Modern English Teacher 9(3): 61-66.

Sainz, M. J. (1992) 'Developing translation skills.'In: Dollerup, C. \& Loddegaard, A. (Eds.) Teaching Translation and Interpreting: Training, Talent and Experience. Amsterdam: John Benjamins.

Sankey, Howard (1991). Incommensurability, translation and understanding. The Philosophical Quarterly, 41(165): 414-426.

Schäffner, C. (1998). Skopos Theory. In Baker, N. (ed.). (1998). The Routledge Encyclopaedia of Translation Studies. London / NY: Routledge.

Schäffner, C. (ed.) (2004) Translation Research and Interpreting Research - Traditions, Gaps and Synergies, Clevedon: Multilingual Matters Ltd

Sharp, C. (2002). Study support and the development of the self-regulated learner. Educational Research,Vol.44, No.1, Pp.29-41.

Simões, Deolinda; Guincho, Helga and Magalhães, Isabel (2013). Teaching languages to European computer science students in an engineering institute in Portugal: translation approaches in the English, German and French classroom. e-TEALS: An e-journal of Teacher 
Education and Applied Language Studies, No. 4 Pp. 4670 .

Snel Trampus, R. D. (2002) 'Aspects of a theory of norms and some issues in teaching translation.'In: Riccardi, A. (Ed.)Translation Studies: Perspectives on an emerging Discipline. Cambridge: Cambridge University Press.

Snell-Hornby, M. (1992). Translation Studies: an integrated approach. Amsterdam: John Benjamins.

Spratt, M., Humphreys, G. and Chan, V. (2002). Autonomy and motivation: which comes first? Language Teaching Research,Vol.6,No.3, Pp.245-266.

Stephens, $\quad \underline{\text { Sharon (2016). Planet Veritas, Planet Veritas }}$ Linkword, Translation, Translation Process. Retrieved on $24^{\text {th }} \quad$ Augustus, Available at.http://www.planetveritas.com/the-importance-oflanguage-translation-and-interpreting/

Sullivan, K. and Lindgren, E. (2002). Self-assessment in autonomous computer-aided second language writing. ELT Journal, 56, 258-266.

Tricás, Mercedes. 1995. Manual de traducción francés-castellano. Gedisa S.A.

Vermes, Albert (2010). Translation in Foreign Language Teaching: A Brief Overview of Pros and Cons. Eger Journal of English Studies X: 83-93.

Vickers, C. H. and Ene, E. (2006). Grammatical accuracy and learner autonomy in advanced writing. ELT Journal, 60, 109-116. 
Vinay, J. P \& Darbelnet, J. (1985/1995). A methodology for translation. In L. Venuti (Ed.), The translation studies reader (Pp. 84-93). London: Routledge.

Yan, ZHANG (2016). Approaches to Teaching Literary Translation, US-China Foreign Language, July 2016, Vol. 14, No. 7, 512-515

Yelena, Nechayeva and Yuliya, Novitskaya (2012). Challenges in teaching translation,

Yumuk, A. (2002). Letting go of control to the learners: the role of the Internet in promoting a more autonomous view of learning in an academic translation course. Educational Research,Vol.44 No.2, Pp.141-156.

Zeng, S. M. and Lu-Chen, J. Y. in Hung, E. (2002) Teaching Translation and Interpreting 4, Building Bridges, Amsterdam: John Benjamins 